UDC 930.26(470+571):(632/633)

Submitted: 25.02 .2020

LBC 63.48(2)-2

Accepted: 29.04 .2020

\title{
INVESTIGATION OF THE PALAEOLITHIC AND MESOLITHIC SITES IN THE DON BASIN ON THE TERRITORY OF VOLGOGRAD REGION
}

\author{
Stanislav O. Remizov \\ Historical, Ethnographic and Architectural Museum-Preserve "Old Sarepta”, Volgograd, Russian Federation
}

\begin{abstract}
The locations of the Stone Age on the Volgograd region territory have been known since the beginning of the XIX century. However, purposeful Stone Age sites explorations had only started after the Sukhaya Mechetka site was discovered by A.P. Koptev and M.N. Grischenko in 1951. The data accumulated on series of stratified sites in Volgograd Region makes it possible to outline two significant groups of them. One of the groups belongs to the Lower Volga basin. The other group is associated with the ramified network of gullies and ravines and multiple tributaries of the Don. The Don is the fourth longest river on the Russian Plain; its basin taken in the Volgograd Region is several times larger than the Volga basin taken in the area. The relatively flat landscape of the Don plain, saturated with small rivers, gullies and ravines, as well as stone raw materials available for mining, have been creating favorable conditions for human habitation since the Middle Paleolithic. The well-known Paleolithic and Mesolithic sites are found both in the watersheds and in the floodplain-terrace areas of the Middle Don. The near-mouth section of the Kurmoyarsky Aksai river - the Don tributary in Kotelnikovo District - and the surroundings of Kremenskaya village in Kletskaya District are standing out in terms of being studied. The stone industry detected in the lower layers of the multilayered site Schlyakh indicates that the Don plain was inhabited by people during the Middle to the Upper Paleolithic transition. The prospects of further searches for Stone Age sites in the Middle Don Basin had already been proven by the discovery of at least forty sites in previous decades. Further archaeological research will help to discover new stratified sites with impressive collections of stone and bone items, which will make it possible to draw analogies with synchronous sites in the territories adjacent to the Volgograd region.
\end{abstract}

Key words: Middle Don basin, Volgograd Region, Stone Age culture sites, Middle Paleolithic, Kurmoyarsky Aksai River, Upper Peleolithic, Novogrigorievskaya archaeological site, Mesolithic, Frolovo archaeological site, Yarovskoye archaeological site.

Citation. Remizov S.O., 2020. Investigation of the Palaeolithic and Mesolithic Sites in the Don Basin on the Territory of Volgograd Region. The Lower Volga Archaeological Bulletin, vol. 19, no. 1, pp. 167-187. (in Russian). DOI: https://doi.org/10.15688/nav.jvolsu.2020.1.9

УДК 930.26(470+571):(632/633)

ББК $63.48(2)-2$

Дата поступления статьи: 25.02.2020

Дата принятия статьи: 29.04.2020

\section{ИССЛЕДОВАНИЯ ПАМЯТНИКОВ ПАЛЕОЛИТА И МЕЗОЛИТА В БАССЕЙНЕ ДОНА НА ТЕРРИТОРИИ ВОЛГОГРАДСКОЙ ОБЛАСТИ}

\author{
Станислав Олегович Ремизов \\ Историко-этнографический и архитектурный музей-заповедник «Старая Сарепта», \\ г. Волгоград, Российская Федерация
}

Аннотация. На территории Волгоградской области местонахождения каменного века известны с начала XIX в., однако целенаправленные разведки для обнаружения стоянок каменного века начались только после открытия А.П. Коптевым и М.Н. Грищенко памятника Сухая Мечётка в 1951 году. Информация о сериях стратифицированных стоянок и местонахождений, накопленная к настоящему времени для Волгоградской области, позволяет выделить две крупные группы памятников. Одна из них связана с бассейном Нижней Волги, а вторая - с разветвленной овражно-балочной сетью и многочисленными притоками Дона. 
Последний является четвертой по протяженности рекой на Русской равнине, его бассейн в Волгоградской области по площади в несколько превосходит бассейн р. Волги. Относительно ровный рельеф Донской равнины, насыщенный мелкими речками, балками и оврагами, доступность каменного сырья создают благоприятные условия для обитания человека еще со времени среднего палеолита. Известные палеолитические и мезолитические местонахождения и стоянки встречаются как на плакорах, так и на надпойменно-террасовых участках Среднего Дона. По степени изученности выделяются приустьевая часть притока Дона - . Курмоярский Аксай в Котельниковском районе и окрестности станицы Кременской в Клетском районе. Каменная индустрия нижних слоев многослойной стоянки Шлях говорит о том, что Донская равнина была заселена людьми и в переходный от среднего к верхнему палеолиту период. Перспективность продолжения поисков памятников каменного века в бассейне Среднего Дона уже доказана обнаружением как минимум четырех десятков местонахождений в предыдущие десятилетия. Дальнейшие археологические исследования будут способствовать обнаружению новых стратифицированных стоянок с выразительными коллекциями каменного и костяного инвентаря, которые позволят проводить аналогии с синхронными памятниками на сопредельных с Волгоградским регионом территориях.

Ключевые слова: бассейн Среднего Дона, Волгоградская область, памятники каменного века, средний палеолит, Курмоярский Аксай, верхний палеолит, Новогригорьевская, мезолит, Фроловская стоянка, Яровское.

Цитирование. Ремизов С. О., 2020. Исследования памятников палеолита и мезолита в бассейне Дона на территории Волгоградской области // Нижневолжский археологический вестник. Т. 19, № 1. С. 167-187. DOI: https://doi.org/10.15688/nav.jvolsu.2020.1.9

\section{История исследования}

Находки изделий, которые можно отнести к различным эпохам каменного века, на территории современной Волгоградской области были отмечены еще в XIX - начале XX в. в публикациях А.Н. Минха «Историко-географический словарь Саратовской губернии: Южные уезды Царицынский и Камышинский» [Минх, 1898, с. 128, 165, 167, 382-383, 392] и Ф.В. Баллода «Приволжские Помпеи» [Баллод, 1923, с. 8-9, 14, 43, 47, 51-52, 58, 63-64, 68]. А.И. Ильина и П.Н. Шишкин в «Материалах к археологической карте Сталинградского, Хопёрского и некоторой части Астраханского и Камышынского округов Нижне-Волжского края» [Ильина, Шишкин, 1929, с. 2-42] приводят множество случаев случайных и «грабительских» находок каменных артефактов.

В 1914 г. в Царицыне основан музей краеведения, в 1924 г. было образовано Общество краеведения. Тогда же, в 1920-е гг., стали проводить археологические раскопки и сборы подъемного материала археологи и краеведы-любители. С 1929 по 1936 г. историческим отделом Сталинградского краеведческого музея заведовала археолог Т.М. Минаева. Кроме проведения раскопок и разведок новых памятников археологии, она работала над коллекциями из фондов музея, вводя их в научный оборот [Минаева, 1929, с. 3-27]. Отправной точкой в проведении раскопок стоянок каменного века является 1929 год. Тогда при проведении рекогносцировочных работ по трассе будущего Волго-Донского судоходного канала археологическим отрядом А.А. Иессена (Государственный Эрмитаж - ГАИМК) на окраине села Ивановка Светлоярского района была найдена и раскопана первая стоянка палеолитического времени на территории Волгоградской области и Донской равнине [Праслов, 1996, с. 31].

В течение двадцати лет, с начала 1930-х до 1950-х гг., сведения о новых находках каменных изделий в основном поступали от специалистов-«неархеологов», обнаруживающих отдельные артефакты во время проведения геологических, геодезических и других работ в пределах области. Сборы подъемного материала на открытых местонахождениях носили случайный характер и были представлены только наиболее выразительными находками.

Знаковым событием для изучения каменного века региона и катализатором продолжения поиска палеолитических памятников в междуречье Волги и Дона послужило открытие в начале 50-х гг. стоянки Сухая Мечётка. Этот памятник последовательно, вслед за переименованиями города сменивший название со Сталинградской на Волгоградскую стоянку, датирован его исследователем С.Н. Замятниным эпохой среднего палеолита и представляет собой остатки сто- 
янки открытого типа. Раскопки Сухой Мечётки вызвали интерес к древней истории Волгоградской области не только у археологов, но и у краеведов. Предпринятые ими в 1960-х 1980-х гг. изыскательские работы привели к открытию более 30 местонахождений. Часть из них обследовал и ввел в научный оборот Н.Д. Праслов, проводивший в эти годы целенаправленные поиски палеолитических памятников в Волго-Донском междуречье [Pемизов, 1992, с. 35].

В 1965 г. Н.Д. Праслов, возглавлявший палеолитический отряд Астраханской экспедиции, провел масштабные разведки на юге Волгоградской области по левобережью Дона в Котельниковском и Октябрьском районах. Результатом исследования прибрежных участков в Котельниковском районе, где шли активные абразивные разрушения четвертичных отложений Цимлянским водохранилищем и размывался целый спектр террас, содержащих мустьерские и верхнепалеолитические материалы [Праслов, 2001, с. 8], было открытие около 15 памятников. В 1971 г. возглавляемый Н.Д. Прасловым палеолитический отряд Волго-Донской экспедиции продолжил исследование в Котельниковском районе позднепалеолитических стоянок Подгородниченково I и II, а также провел археологические разведки выше по течению Дона, в Иловлинском и Клетском районах и по левому притоку Дона р. Иловле, в результате которых был открыт ряд новых палеолитических и мезолитических памятников.

Открытие в 1988 г. В.И. Куфенко стоянки у хутора Шляховского во Фроловском районе стало причиной более пристального внимания ученых к поискам и изучению памятников каменного века в центральной части Волгоградской области во Фроловском, Иловлинском и Клетском районах. Исследования в 1990-1991, 1999-2001 и 2013 гг. многослойной стоянки Шлях Среднедонской палеолитической экспедицией под руководством П.Е. Нехорошева (Институт истории материальной культуры, далее - ИИМК РАН) позволило выделить и изучить в каменной индустрии памятника переходный этап от среднего к верхнему палеолиту. Археологическими разведками экспедиции было обследовано левобережье Дона от станицы Клетской до хутора Старояблоновский Иловлинского района, в результате которых были открыты и введены в научный оборот верхнепалеолитическая стоянка Новогригорьевская, мезолитические местонахождения Селезневское и Яровское.

В 1999-2000 гг. автором в районе станицы Кременской Клетского района были найдены еще 6 местонахождений палеолитического и мезолитического возраста, в 2001 г. была исследована мезолитическая стоянка Фроловская, в 2001, 2002 и 2004 гг. - местонахождение Яровское.

Площадь бассейна Дона в Волгоградском регионе в несколько раз превышает площадь бассейна Волги. Водораздел между двумя реками проходит по верхним отметкам Приволжской и Ергенинской возвышенностей, расположенных параллельно руслу Волги и удаленных от него на небольшое, до нескольких десятков километров, расстояние. Соответственно, сток практически всех водных потоков Волго-Донского междуречья направлен в сторону Дона. Территория междуречья изрезана широкой сетью балок, логов, оврагов, руслами средних и малых рек, сезонных и высохших речек, равнинный рельеф имеет незначительные возвышения. Все эти факторы создавали привлекательные условия для жизни, охоты древних людей, которые оставили здесь большее количество следов своего пребывания.

Во Фроловском (хут. Шляховской), в Клетском (ст. Кременская), в Жирновском (г. Жирновск, пос. Линево) районах выходят на поверхность известняки верхнего отдела каменноугольного периода, содержащие кремневое сырье. Такой кремень встречается в виде продуктов расщепления на большом количестве памятников Волгоградского региона (от среднего палеолита до мезолита), что позволяет сделать предположение о его доступности для человека в древности везде, где существовали естественные обнажения четвертичных пород.

Все известные памятники каменного века на территории Донского бассейна Волгоградской области расположены неравномерно. На фоне единичных, «разбросанных» по карте региона памятников выделяются две географические локальности (в описании памятни- 
S.O. Remizov. Investigation of the Palaeolithic and Mesolithic Sites

ков ниже они даются отдельно), где на относительно малой площади концентрация местонахождений очень высокая: это долина в устье р. Курмоярский Аксай и прилегающее к ней побережье Цимлянского водохранилища в Котельниковском районе и правобережье Малой излучины Дона у станицы Кременской в Клетском районе [Ремизов, 2001б]. Изученность каменного века междуречья в целом остается низкой, исключением являются отдельные участки во Фроловском и Иловлинском районах.

К сожалению, разной остается и индивидуальная информативная составляющая для каждого памятника. Культурный слой зафиксирован на единицах, большинство коллекций представлено подъемным материалом, количество которого на разных памятниках является неравнозначным. Так, в настоящем исследовании не учитывались, за редким исключением, пункты, содержащие единичные находки. Уточнение сведений (условия залегания, площадь распространения находок и пр.) по некоторым памятникам, открытым 40-60 лет назад, стало в настоящее время невозможным по ряду объективных и субъективных причин.

\section{Памятники палеолита и мезолита} бассейна р. Дон

\section{Курмоярский Аксай и прилегающий к нему участок побережья Цимлянского водохранилища}

\section{Большая Козловая балка I}

Местонахождение обнаружено палеолитическим отрядом Астраханской экспедиции под руководством Н.Д. Праслова в 1965 г. [Праслов, 1965]. Оно удалено от устья одноименной балки к северу на расстояние около 1 км (рис. 2,6) и приурочено к береговому обнажению мариининской террасы Дона. Общая мощность обнажения, в котором выделяются 2 горизонта ископаемых почв, составляет около 20 метров. Под одной из почв обнаружен костеносный горизонт, содержащий останки слона, лошади раннего типа, зубра или быка, гигантского оленя [Праслов, 1967, c. 121]. Под обнажением террасы собрано око- ло 30 кремней. Из них 5 отщепов и шаровидный нуклеус сильно окатаны и происходят из аллювиальных отложений. Остальные находки относятся, по всей видимости, к покровным отложениям. Это 2 шаровидных нуклеуca, обломок остроконечника, скобель на удлиненном пластинчатом отщепе, массивное скребло со слегка выпуклым рабочим краем и около 10 отщепов. Находки не окатаны и не патинизированы. Местонахождение предварительно датировано временем среднего палеолита [Праслов, 1968, с. 142].

Материалы хранятся в Астраханском краеведческом музее и в ИИМК РАН.

\section{Большая Козловая балка II}

Местонахождение обнаружено палеолитическим отрядом Астраханской экспедиции под руководством Н.Д. Праслова в 1965 г. [Праслов, 1965]. Оно находится на левом мысу, образованном устьем Большой Козловой балки и берегом Курмоярского Аксая (рис. 2,7). Здесь в суглинке на глубине около 3 м найден кремневый отщеп. Местонахождение условно датировано временем палеолита.

Материалы хранятся в ИИМК РАН.

\section{Большая Козловая балка III}

Местонахождение обнаружено палеолитическим отрядом Астраханской экспедиции под руководством Н.Д. Праслова в 1965 г. [Праслов, 1965]. Оно расположено напротив местонахождения Большая Козловая балка II, на правом приустьевом мысу балки (рис. 2,8). В волноприбойной зоне найден подъемный материал: двустороннеобработанное орудие среднепалеолитического облика и несколько осколков костей лошади «кабалоидного облика» (определение И.М. Громова).

Материалы хранятся в ИИМК РАН.

\section{Весельй}

Местонахождение обнаружено палеолитическим отрядом Астраханской экспедиции под руководством Н.Д. Праслова в 1965 г. [Праслов, 1965] в окрестностях хутора Веселый Котельниковского района (рис. 2,3). Несколько обработанных кремней найдено на 
берегу Цимлянского водохранилища. Возраст местонахождения - в границах от палеолита до мезолита.

Материалы хранятся в ИИМК РАН.

\section{Нагавская I}

Местонахождение обнаружено и обследовано палеолитическим отрядом Астраханской экспедиции под руководством Н.Д. Праслова в 1965 г. [Праслов, 1965] на южной окраине станицы Нагавской Котельниковского района (рис. 2,1). Единичные находки кремневых отщепов и осколков сделаны на площадке, образованной берегом Цимлянского водохранилища и двумя небольшими безымянными овражками. Местонахождение относится к эпохе каменного века, более точное определение возраста не представляется возможным.

Материалы хранятся в ИИМК РАН.

\section{Нагавская II}

Местонахождение обнаружено и обследовано палеолитическим отрядом Астраханской экспедиции под руководством Н.Д. Праслова в 1965 г. [Праслов, 1965]. Оно расположено в 1 км к западу от станицы Нагавской Котельниковского района, на правом склоне балки Карайчева, недалеко от ее устья (рис. 2,2). Локальное скопление находок обнаружено на участке $15 \times 15$ м на современной дневной поверхности, развившейся на нагавских глинах [Праслов, 1968, с. 142]. Всего собран 31 предмет, в том числе боковое скребло, два зубчатых изделия, обломок нуклеуса, серия массивных отщепов. Находки окатаны, на современной поверхности оказались благодаря выносу рыхлых четвертичных отложений. Местонахождение датировано раннепалеолитическим возрастом [Праслов, 1967, c. 122].

Материалы хранятся в Астраханском краеведческом музее и в ИИМК РАН.

\section{Подгородниченково I}

Стоянка обнаружена палеолитическим отрядом Астраханской экспедиции под руководством Н.Д. Праслова в 1965 г. [Праслов, 1965] в Котельниковском районе, в 2-2,5 км к северо-востоку от устья Большой Козловой балки (рис. 2,4), исследовалась Н.Д. Прасловым [Праслов, 1966; Праслов, 1971]. В устье небольшой, но древней балочки, выходящей в затопленную ныне долину р. Курмоярский Аксай, на левом берегу найдено несколько изделий из кремня. Исследования местонахождения [Праслов, 1967, с. 124-126] выявили культурный слой, залегавший на глубине около 1,2 метра. Коллекция найденных изделий составляет более 500 экз. Большую часть составляют целые и фрагментированные пластины. Орудия представлены скреблом, скребком и тремя боковыми резцами, есть один призматический нуклеус. Стоянка датирована временем позднего палеолита.

Материалы хранятся в Астраханском краеведческом музее и в ИИМК РАН.

\section{Подгородниченково II}

Местонахождение обнаружено палеолитическим отрядом Астраханской экспедиции под руководством Н.Д. Праслова в 1965 г. [Праслов, 1965] в Котельниковском районе, в 2-2,5 км к северо-востоку от устья Большой Козловой балки, в 150-200 м севернее первого местонахождения, на левом борту безымянной балочки (рис. 2,5). Найдено 3 кремневых изделия, в том числе боковой резец. Рядом, в волноприбойной зоне, обнаружен фрагмент фоссилизированной кости. Местонахождение датировано верхним палеолитом.

Материалы хранятся в Астраханском краеведческом музее и в ИИМК РАН.

\section{Похлебинское I}

Местонахождение обнаружено палеолитическим отрядом Астраханской экспедиции под руководством Н.Д. Праслова в 1965 г. [Праслов, 1965] в 1 км к северу от хутора Похлебин Котельниковского района, недалеко от устья Малой Козловой балки, в волноприбойной зоне залива Курмоярского Аксая (рис. 2,9). Находки сосредоточены на ограниченном участке. Собрано около 70 кремневых предметов: нуклеусы призматические, многочисленная группа резцов (боковых, срединных, угловых, комбинированных), редкие и маловыразительные скребки, пластины и отщепы. 
Изделия не окатанные, многие со следами известковой корки. Высокий уровень призматической техники расщепления у нуклеусов, разнообразие типов резцов позволяет уверенно датировать местонахождение временем верхнего палеолита.

Материалы хранятся в Астраханском краеведческом музее и в ИИМК РАН.

\section{Похлебин II}

Местонахождение обнаружено палеолитическим отрядом Астраханской экспедиции под руководством Н.Д. Праслова в 1965 г. [Праслов, 1965] под обнажением II надпойменной террасы между хутором Похлебин Котельниковского района и устьем впадающей в Курмоярский Аксай речки Сиберечной (рис. 2,10). Кремневый нуклеус и нуклевидный обломок найдены на высоте около 2 м над урезом залива Курмоярского Аксая. Призматическая техника расщепления нуклеуса позволяет датировать местонахождение позднепалеолитическим временем.

Материалы хранятся в Астраханском краеведческом музее и в ИИМК РАН.

\section{Цыганский хутор}

Местонахождение обнаружено палеолитическим отрядом Астраханской экспедиции под руководством Н.Д. Праслова в 1965 г. [Праслов, 1965]. Оно расположено в Котельниковском районе, на правом берегу залива p. Курмоярский Аксай, в урочище Цыганский хутор (рис. 2,11). Находки каменных изделий и обломки костей ископаемых животных были сделаны под обнажением II надпойменной террасы в волноприбойной зоне. Место сбора подъемного материала занимает около 70 м береговой зоны. На уровне пляжа в слое светло-бурого лессовидного суглинка in situ pacчищено несколько обломков костей мамонта.

Всего обнаружено 61 каменное изделие. Восемь нуклеусов были представлены дисковидными, шаровидными и грубопризматическими экземплярами. Кроме нуклевидных обломков, отщепов с массивными ударными площадками, найдены 2 скребла, 2 отщепа со вторичной обработкой. Архаический облик каменного инвентаря и характерные особеннос- ти в технике расщепления позволяют датировать местонахождение временем среднего палеолита [Праслов, 1968, с. 142].

Материалы хранятся в Астраханском краеведческом музее и в ИИМК РАН.

\section{Малая излучина Дона \\ в окрестностях станицы Кременской}

\section{Доломановская балка}

Местонахождение каменного века обнаружено палеолитическим отрядом Волго-Донской экспедиции под руководством Н.Д. Праслова в 1971 г. [Праслов, 1971] за западной окраиной станицы Кременской Клетского района (рис. 3,31). Расположено на левом берегу балки, отделяющей ныне несуществующий хут. Доломановку от станицы Кременской. Культурный слой невыразительный, залегает в основании современной почвы. Обнаружено 8 предметов, в том числе нуклеус, массивная ассиметричная пластина с негативами сколов, скребло, отщепы, фрагмент пластины. Кроме того, среди находок имеются 9 фрагментов керамики гончарного производства, а также сильно окатанный кусок ожелезненной породы темно-вишневого цвета.

Н.Д. Праслов определил местонахождение Доломановская балка как поселение эпохи бронзы из-за находок фрагментов керамики. Однако это предположение возможно лишь в случае, если будет установлена одновременность их функционирования с каменным инвентарем. Судя по каменному инвентарю, местонахождение может быть датировано временем верхнего палеолита - мезолита. В случае же, если фрагменты керамики синхронны по времени с каменным инвентарем, то возраст местонахождения будет с большей долей вероятности соответствовать периоду неолита - энеолита.

Материалы хранятся в ИИМК РАН.

\section{Кременская I}

Местонахождение обнаружено палеолитическим отрядом Волго-Донской экспедиции под руководством Н.Д. Праслова в 1971 г. [Праслов, 1971]. Оно расположено на левом берегу балки Симонова примерно в одном 
километре к югу от станицы Кременской Клетского района (рис. 3,27), на террасовой площадке вдоль земляного вала. Подъемный материал включает 12 предметов: нуклеус, отщепы, изделие на отщепе, фрагмент кремневого бифасиального изделия и осколки.

Предположительные возрастные границы памятника - от верхнего палеолита до неолита.

Материалы хранятся в ИИМК РАН.

\section{Кременская II}

Местонахождение обнаружено палеолитическим отрядом Волго-Донской экспедиции под руководством Н.Д. Праслова в 1971 г. [Праслов, 1971]. Расположено к востоку от станицы Кременской Клетского района, на крутом склоне правого борта балки Каменной (или Каменки) (рис. 3,28). При выравнивании дороги был слегка прорезан склон, в получившейся канаве обнаружен археологический материал. Общее количество находок 26 экземпляров. В коллекцию найденных предметов входят нуклеусы, пластины, отщепы, скребло, изделие на отщепе.

Предположительные возрастные границы памятника - от верхнего палеолита до неолита.

Материалы хранятся в ИИМК РАН.

\section{Кременская III}

Местонахождение обнаружено палеолитическим отрядом Волго-Донской экспедиции под руководством Н.Д. Праслова в 1971 г. [Праслов, 1971] в окрестностях станицы Кременской Клетского района. Отдельные предметы обнаружены на платообразной поверхности рядом с триангуляционным пунктом (рис. 3,29). Рассеянное по поверхности местонахождение не имеет четких границ, от местонахождения Кременская II удалено на небольшое расстояние. Подъемный материал состоит из нуклеусов, отщепов с ретушью и без ретуши, а также нескольких фрагментов керамики. Предположительные возрастные границы памятника - от верхнего палеолита до неолита.

Материалы хранятся в ИИМК РАН.
Кременская IV

Местонахождение открыто С.О. Ремизовым в 1999 г. [Ремизов, 2000]. Находится примерно в двух километрах от западной окраины станицы (рис. 3,30), на второй надпойменной террасе Дона, изрезанной молодыми глубокими овражками. Находки в количестве 60 предметов приурочены к верхнему гумусированному слою современной почвы. Кремневые артефакты представлены фрагментом незаконченного двустороннеобработанного орудия, пластиной, отщепами, чешуйками, осколками и обломками.

Предположительные возрастные границы памятника - от мезолита до неолита.

Материалы хранятся в Волгоградском областном краеведческом музее.

\section{Балка Селезнева}

В 1990-1991 гг. разведочным отрядом Среднедонской палеолитической экспедицией под руководством П.Е. Нехорошева в русле балки Селезнева, выходящей устьем к ст. Кременской Клетского района, на всем ее протяжении было собрано более сотни предметов [Нехорошев, 1991; Нехорошев, 1992а, c. 15], отнесенных к эпохе каменного века, среди которых есть орудия, нуклеусы и нуклевидные предметы, пластины и отщепы. Разная степень патинизации и сохранности, морфология некоторых предметов указывают на разновременность находок - от среднего до верхнего палеолита. С целью выяснения происхождения этих материалов склоны балки Селезнева и примыкающих к ней небольших оврагов были подвергнуты дополнительному изучению. В результате в разные годы здесь обнаружено 5 новых местонахождений каменного века.

Материалы хранятся в ИИМК РАН.

\section{Селезневское I}

Местонахождение открыто разведочным отрядом Среднедонской палеолитической экспедицией под руководством П.Е. Нехорошева в 1990 г. [Нехорошев, 1991]. Расположено в 6 км к югу от станицы Кременской Клетского района, в верховьях одноименной балки, 
на ее правом берегу (рис. 3,32). Исследовалось П.Е Нехорошевым в 1990-1991 гг. [Нехорошев, 1990; Нехорошев, 1991], Л.Б. Вишняцким в 1999 г. [Вишняцкий, 1999]. Подъемный материал приурочен к верхней горизонтальной поверхности, примыкающей к балке, и рассеян в верхнем слое почвы мощностью до 20-30 см. Площадь распространения не менее 3000 кв. метров. Всего за годы изучения здесь собрано 933 предмета. В состав коллекции входят: орудия и изделия со вторичной обработкой, нуклеусы и нуклевидные, сколы, чешуйки и мелкие обломки, а также галькаотбойник. Количественный состав, характер материала, приуроченность памятника к выходам сырья - все это указывает на то, что местонахождение использовалось как мастерская первичного расщепления камня [Нехорошев, 1995, с. 55]. Археологический возраст материала местонахождения Селезневское I определен как послепалеолитический.

Материалы хранятся в ИИМК РАН.

\section{Селезневское II}

Местонахождение обнаружено С.О. Ремизовым в 1999 г. [Ремизов, 2000]. Оно расположено на склоне правого борта балки Селезнева за юго-западной окраинной станицы Кременской (рис. 3,33). Находки собраны в осыпи небольшого овражка, прорезающего верхнюю кромку борта балки, и на прилегающем к нему склоне. Коллекцию подъемного материала составляют скребло, отщепы, пластинчатый отщеп, осколки. Предварительно датирование местонахождения - от палеолита до мезолита.

Материалы хранятся в Волгоградском областном краеведческом музее.

\section{Селезневское III}

Местонахождение каменного века открыто С.О. Ремизовым в 1999 г. [Ремизов, 2000]. Местонахождение расположено по обоим бортам одноименной балки за юго-западной окраиной станицы Кременской Клетского района (рис. 3,34). Подъемный материал состоит из отщепов с ретушью и без ретуши, осколков. Предварительно датирование местонахождения - от палеолита до мезолита.
Находки хранятся в Волгоградском областном краеведческом музее.

\section{Селезневское IV}

Местонахождение каменного века открыто С.О. Ремизовым в 1999 г. [Ремизов, 2000]. Подъемный материал в количестве 28 предметов собран в осыпи стенок небольших овражков, прорезающих верхнюю кромку одноименной балки, а также в осыпи верхней части балки (рис. 3,35 ). Среди находок: скребло, нуклевидные изделия, дистальный фрагмент пластины высокой формы, отщепы и осколки, а также две сильно окатанных гальки из окаменевшей слоистой глины. Вопрос датировки местонахождения проблематичен. Варианты - от верхнего палеолита до мезолита.

Находки хранятся в Волгоградском областном краеведческом музее.

\section{Селезневское V}

Местонахождение каменного века открыто С.О. Ремизовым в 2000 г. [Ремизов, 2001a]. Оно расположено за юго-восточной околицей станицы Кременской, в основании правого бора балки Селезнева (рис. 3,36). Всего найдено 5 предметов, в том числе грубопризматический нуклеус, отщепы и пластина. Предварительно датирование местонахождения - от палеолита до мезолита.

Находки хранятся в Волгоградском областном краеведческом музее.

\section{Симоновское}

Местонахождение каменного века открыто С.О. Ремизовым в 2000 г. [Ремизов, 2001a]. Удалено от восточной окраины станицы Кременской на расстояние около 1 км (рис. 3,37$)$. Площадь сбора подъемного материала - около 800 кв. метров. Всего обнаружено 33 предмета, в том числе несколько орудий, отщепы и осколки. Предварительно датирование местонахождения - от верхнего палеолита до мезолита.

Находки хранятся в Волгоградском областном краеведческом музее. 


\section{Александровка}

Стоянка открыта В.И. Куфенко в 1982 г. [Куфенко, 1990, с. 64] на р. Медведица у с. Александровка Жирновского района (рис. 1,39). Культурный слой залегает на глубине $0,4-0,7$ м. Каменные изделия не окатаны. Подъемный материал включает нуклеусы, орудия (скребки и долотовидные орудия), сколы. В основе каменной индустрии находится ножевидная пластина средних и небольших размеров. Исходя из анализа инвентаря, техники расщепления памятник можно отнести к средней поре верхнего палеолита.

Находки хранятся в музее станции юных техников (г. Волжский).

\section{Ивановка I}

Стоянка у с. Ивановка Светлоярского района (рис. 1,14 ) открыта А.А. Йессеном в 1929 г. [Береговая, 1984, с. 78] во время рекогносцировочных работ по трасе будущего Волго-Донского канала. Расположено в ложе спускового лотка опытного бассейна на правом берегу р. Кучерда, напротив южной окраины села. Вдоль восточного борта бассейна был заложен раскоп длиной 7,5 м и глубиной 2,5 м. Первые находки, около 100 каменных изделий, составили призматические нуклеусы, резцовые сколы, концевые скребки, отщепы [Праслов, 1996, с. 32-33]. В 1965 г. окрестности села Ивановка были обследованы Н.Д. Прасловым [Праслов, 1965]. В подъемный материал вошли нуклеус, скребок, несколько расщепленных фрагментов кремня. Стоянка датирована временем верхнего палеолита.

Материал хранится в Государственном Эрмитаже.

\section{Ивановка II}

Местонахождение открыто Н.Д. Прасловым в 1965 г. [Праслов, 1965]. Расположено на левом берегу запруженной р. Кучерда, напротив центра с. Ивановка (рис. 1,15). В земляных выкидах из окопов времен Великой Отечественной войны собрано несколько кремней, в том числе концевой скребок на отщепе. В береговом обрыве на глубине око- ло 0,3 м в желто-буром суглинке, подстилающем современную почву полного профиля, найдено несколько расколотых фоссилизированных костей животных. Предварительно датировано временем верхнего палеолита.

Материал хранится в Астраханском краеведческом музее и в ИИМК РАН.

\section{Ивановка III}

Местонахождение открыто Н.Д. Прасловым в 1965 г. [Праслов, 1965]. Расположено на левом берегу запруженной р. Кучерда, примерно в 300 м от юго-восточной окраины села (рис. 1,16). Собрано 7 осколков кремня со следами обработки. Напротив, на правом берегу p. Кучерда, в суглинке на глубине около 1,5 м обнаружены кварцитовая патинизированная пластинка и кремневый отщеп, покрытый известковой корочкой.

Материал хранится в ИИМК РАН.

\section{Ивановка IV}

Местонахождение открыто С.О. Ремизовым в 1995 году. Расположено на левом берегу р. Кучерда за юго-западной окраиной с. Ивановка (рис. 1,17), ниже дамбы, по которой проходит дорога - въезд в село. В верхней части осыпи небольшого оврага найдено 65 предметов. Большую часть составляют сколы: отщепы и фрагменты отщепов, пластины, микропластины - всего 53 экземпляра. Орудия представлены скреблом, долотовидным (1 экз.) и выемчатыми (2 экз.) орудиями. Предварительно памятник датирован временем мезолита - неолита.

Материал готовится к передаче в музейзаповедник «Старая Сарепта» (г. Волгоград).

\section{Колпачки}

Местонахождение обнаружено в 1934 г. геологами С.С. Прониным и 3.Н. Барановской [Горецкий, 1952, с. 310; Праслов, 1967, c. 122] в 9 км от города Калач-на-Дону (рис. 1,13). На берегу речки Карповки, левого притока Дона, в местности Колпачки были найдены 3 удлиненных кремневых отщепа со следами неглубокой патины, предположительно отнесенных к верхнему палеолиту. Отще- 
пы найдены in situ в лессовидных суглинках и супеси II надпойменной террасы на глубине около 9 метров.

Материал хранится в ИИМК РАН.

\section{Логовское}

Находка массивного кварцитового скребла архаического облика была сделана Ю.М. Васильевым в 1963 г. [Береговая, 1984, c. 23; Праслов, 1967, с. 120-121] в отложениях третьей надпойменной террасы левого берега Дона, западнее пос. Логовского Калачевского района (рис. 1,12). В 1965 г. местонахождение обследовалось Н.Д. Прасловым [Праслов, 1965], который предварительно датировал находку раннепалеолитическим временем.

Материал хранится в ИИМК РАН.

\section{Новогригорьевская стоянка}

Стоянка открыта в 1991 г. при проведении поисковых работ Среднедонской палеолитической экспедицией ЛОИА АН СССР (ИИМК РАН) [Нехорошев, 1991]. Находится у северной окраины станицы Новогригорьевской Иловлинского района (рис. 1,23). Исследовалась П.Е. Нехорошевым [Нехорошев, 1991], Л.Б. Вишняцким [Вишняцкий, 2000]. Культурный слой мощностью 20-30 см залегает на глубине 1,35 метра. Подъемный материал включает 3053 предмета, в том числе нуклеусы и нуклевидные изделия, орудия (резцы, скребки, комбинированные орудия, проколки, скребло, сколы с ретушью), сколы в виде отщепов, пластин, микропластин, многочисленные отходы производства. Условия залегания археологического материала, типология орудий и характер технических приемов снятия сколов-заготовок указывают на верхнепалеолитический возраст стоянки [Нехорошев, 1994; Нехорошев, 2006а, с. 79].

Материал хранится в ИИМК РАН.

\section{Tapbl I, II}

В 1969 г. разведочным отрядом под руководством Н.Д. Праслова [Праслов, 1970] в окрестностях с. Тары Иловлинского района (рис. 1,21-22) было обнаружено два место- нахождения каменного века. Сборы с первого включают 27 предметов, в том числе нуклеус призматический, скребок концевой, отщепы, осколки, обломки, а также фрагмент дна керамического изделия гончарного производства. Сборы со второго местонахождения составляют 15 предметов: призматический нуклеус, отщепы и осколки.

Коллекции хранятся в ИИМК РАН.

\section{Фроловская стоянка}

Стоянка находится в десяти километрах к юго-западу от г. Фролово, районного центра в Волгоградской области (рис. 1,26). Открыта местным краеведом Е.Н. Хюппененом в начале 1980-х гг., исследовалась С.О. Ремизовым в 1999 и 2001 гг. [Ремизов, 2000; 2002]. Расположена на крутой излучине левого берега балки Паника. Находки встречаются на современной дневной поверхности и в голоценовой почве. Коллекция состоит из 184 предметов. Среди находок есть большая группа орудий (скребло, скребки, проколки), нуклеусы и нуклевидные изделия, сколы в виде отщепов и пластин. Стоянка предварительно датируется мезолитическим временем [Ремизов, 2003-2004, с. 270].

Находки хранятся в краеведческом музее г. Фролово.

\section{Шашкин}

Местонахождение обнаружено волгоградским палеонтологом А.А. Ярковым в окрестностях хутора Шашкин Серафимовичского района [Праслов, 1984, с. 95, рис. $37^{1}$ ]. В береговом обрыве р. Медведица, примерно в 7 метрах над урезом воды, рядом с костеносным горизонтом, включающим останки эласмотерия и хазарской лошади, найден кремневый остроконечник [Ярков, 2005, с. 303]. Местонахождение датировано временем среднего палеолита.

Находка хранится в ИИМК РАН.

\section{Шлях}

Многослойная стоянка в районе хутора Шляховского Фроловского района (рис. 1,25) открыта краеведом из г. Волжского В.И. Ку- 
фенко в 1988 г. [Нехорошев, 1990]. Археологические исследования проводились с перерывами в 1990-2013 гг. экспедицией ИИМК РАН под руководством П.Е. Нехорошева [Нехорошев, 1990; 1991; 1999; 2000; 2001; Нехорошев и др., 2015].

Артефакты, найденные на дневной поверхности памятника, в современной почве и слое $2 \mathrm{C}$, относятся к мезолиту, материалы из нижележащих слоев - к палеолиту.

Слой 4С насчитывает 150 находок орудий и продуктов расщепления и по результатам естественнонаучных анализов датируется 32-33 тыс. лет.

Находки из слоя 6 (86 предметов) представлены отщепами, пластинами и чешуйками. По облику некоторых изделий возраст слоя датирован верхним палеолитом в диапазоне 34-36 тыс. лет.

Коллекция каменных изделий из слоя 7 насчитывает 106 предметов и состоит из орудий, нуклеусов и нуклевидных изделий, а также сколов. Невыразительность материала не позволяет отнести его к среднему или верхнему палеолиту. Возраст погребенной почвы из данного слоя сопоставляется с первой половиной кашинского (молодовского) оледенения (39-37 тыс. лет).

Коллекция каменного инвентаря из слоя 8 насчитывает 4558 предметов, куда вошли орудия (остроконечники, скребла, ножи, скребки, проколки, резцы, зубчато-выемчатые и другие орудия), нуклевидные изделия и сколы (отщепы и пластины). По П.Е. Нехорошеву, технология первичного расщепления камня указывает на переходный от среднего к верхнему палеолиту характер памятника [Нехорошев, 1992б].

Слой 9 представлен 862 находками: орудия (скребла, скребки, резцы, проколка, другие орудия и сколы с ретушью), нуклеусы и сколы в виде отщепов и пластин. Слой балочного аллювия, в котором были сделаны находки, имеет серию датировок в рамках $42-$ 44 тыс. лет) [Нехорошев, 2006б].

Материалы хранятся в ИИМК РАН.

\section{Ютаевка I}

Местонахождение обнаружено разведочным отрядом под руководством Н.Д. Прас- лова в 1969 г. [Праслов, 1970] у с. Ютаевка Иловлинского района, на правобережье p. Иловля (рис. 1,18). Каменные изделия из палеогенового кварцитоподобного песчаника и кремня собраны на высоком правом берегу p. Иловля у северо-восточной окраины села. Культурный слой не обнаружен. Находки локализированы на высоком меловом мысу, на котором отсутствуют рыхлые четвертичные покровы. Это местонахождение предварительно отнесено П.Д. Прасловым к среднепалеолитическому времени.

Материалы хранятся в ИИМК РАН.

\section{Ютаевка II}

Местонахождение обнаружено разведочным отрядом под руководством Н.Д. Праслова в 1969 г. [Праслов, 1970] у с. Ютаевка Иловлинского района, на правобережье р. Иловля (рис. 1,19). Оно приурочено к выходам древнебалочных ергенинских песков, представляет собой остатки мастерской по изготовлению каменных орудий. Предварительная датировка местонахождения: поздний палеолит - мезолит.

Материалы хранятся в ИИМК РАН.

\section{Ютаевка III}

Местонахождение обнаружено разведочным отрядом под руководством Н.Д. Праслова в 1969 г. [Праслов, 1970] у с. Ютаевка Иловлинского района, на правобережье р. Иловля (рис. 1,18). В 1,5 км северо-восточнее села на склоне высокого берега обнаружено скопление кремневых отщепов, отнесенных к мезолитическому времени.

Материалы хранятся в ИИМК РАН.

\section{Яровское}

Местонахождение открыто в 2000 г. П.Е. Нехорошевым (Среднедонская палеолитическая экспедиция ИИМК РАН) [Нехорошев, 2000]. Исследовалось С.О. Ремизовым в 2001, 2002 и 2004 гг. [Ремизов, 2002; 2003 ; 2005]. Расположено в окрестностях станицы Новогригорьевской Иловлинского района (рис. 1,24). Находки залегали на поверхности современной почвы и в верхнем гуму- 
сированном слое вперемешку с кварцитовым сырьем в виде крупных фрагментов. Общая площадь сбора подъемного материала составила около 13 тыс. кв. м, коллекция каменных изделий насчитывает 213 предметов. Это нуклеусы, заготовки нуклеусов, орудия (скребла, двустороннеобработанные орудия, зубчато-выемчатые орудия, резец), сколы в виде отщепов и пластин с ретушью и без ретуши. Количественный состав, характер материала, приуроченность памятника к выходам сырья - все это указывает на то, что местонахождение использовалось как мастерская первичного расщепления камня. Возраст памятника предположительно определен как мезолитический.

Находки хранятся в Волгоградском областном краеведческом музее и в музее-заповеднике «Старая Сарепта».

\section{Заключение}

С момента раскопок первой на территории Волгоградской области стоянки эпохи палеолита у с. Ивановки прошло 90 лет. За это время на территории региона в бассейнах рек Волги и Дона было открыто большое количество памятников каменного века. Точное их число назвать сейчас трудно: сведения о некоторых в силу различных причин утеряны, часть материалов находится в работе, данные по некоторым местонахождениям приходится собирать заново.

За 30 лет удалось собрать сведения почти о девяноста памятниках. Они относятся к разным периодам каменного века - от среднего палеолита до мезолита. Объем сведений и степень изученности каждого из местонахождений - различны. Поэтому назрела необходимость первичной систематизации накопленного материала.

Все памятники условно были разделены на две группы - по бассейнам двух основных рек Европейской части России Волги и Дона, протекающих по территории Волгоградского региона. Материалы по палеолитическим и мезолитическим памятникам Нижнего Поволжья уже опубликованы [Ремизов, 2019], материалы по Среднему Дону представлены в настоящей работе.

Количество памятников в обоих группах различно, так как при выборе района поиска исследователи, как правило, руководствовались своими возможностями - чем удаленнее район от областного центра, тем меньше становится концентрация местонахождений. Это характерно для исследований краеведов, научные экспедиции руководствовались другим принципом: археологические разведки проводились в окрестностях (ближних и дальних) памятника, на котором велись раскопки. Исключением являются исследования Н.Д. Праслова - его научные интересы распространялись на все междуречье Волги и Дона.

В каждом из выделенных бассейнов есть памятники с достаточно выразительными находками, количество которых (при условии наличия элементарных данных по геологии и палеозоологии) позволяет проводить сравнительные анализы с другими памятниками Волго-Донского междуречья и, что важно, с памятниками, расположенными в регионах, соседствующих с Волгоградской областью. На территориях Саратовской области это верхнепалеолитические микрорайоны севера Саратовского правобережья и Саратовское Заволжье, стоянки в районе с. Непряхино [Малов, 2012, с. 18-19]. Мезолитические памятники в Саратовской области в основном привязаны к песчаным возвышениям южнее г. Энгельса, в Хвалынском районе, а также в степном Саратовском Заволжье [Малов, 2012, c. 23]. В Воронежской области - в первую очередь верхнепалеолитический комплекс памятников в Костёнковско-Борщёвском районе. В Ростовской области - комплекс памятников палеолита в Бирючьей балке, а также памятники среднего палеолита в бассейне Миуса и на Нижнем Дону [Праслов, 1968, c. 64]. В Астраханской области и на границе с Западным Казахстаном выделена группа мезолитических памятников, расположенных в северо-прикаспийской впадине, рассматриваемых в рамках одной индустриальной «сероглазовской» традиции [Малов, 2012, с. 22] На территории Республики Калмыкия в зоне верхнехвалынской равнины также выделены комплексы мезолитических стоянок дюнного типа [Малов, 2012, с. 23]. Перечисленные группы образуют комплекс южно-русских и Прикаспийских памятников каменного века степной зоны, потенциал дальнейшего изучения ко- 
торых до сих пор еще не обозначен. Необходимость в появлении новых обобщающих работ для этого отдельного региона, находящегося на стыке Русской равнины и Северного Кавказа, очевидна [Ремизов, 2019, с. 188-189].

В ближайшей перспективе необходимо продолжить и работу по накоплению данных об особенностях залегания каждого из памятников Волгоградской области и изучению степени его сохранности. Систематизация таких данных будет способствовать выявлению закономерностей для поиска новых местонахождений каменного века.

\section{ПРИМЕЧАНИЕ}

1 Здесь ошибочно указано место находки хут. Шакин Кумылженского района. Правильно: хут. Шашкин Серафимовичского района (устное замечание автора находки А.А. Яркова). 


\section{ИЛЛЮСТРАЦИИ}

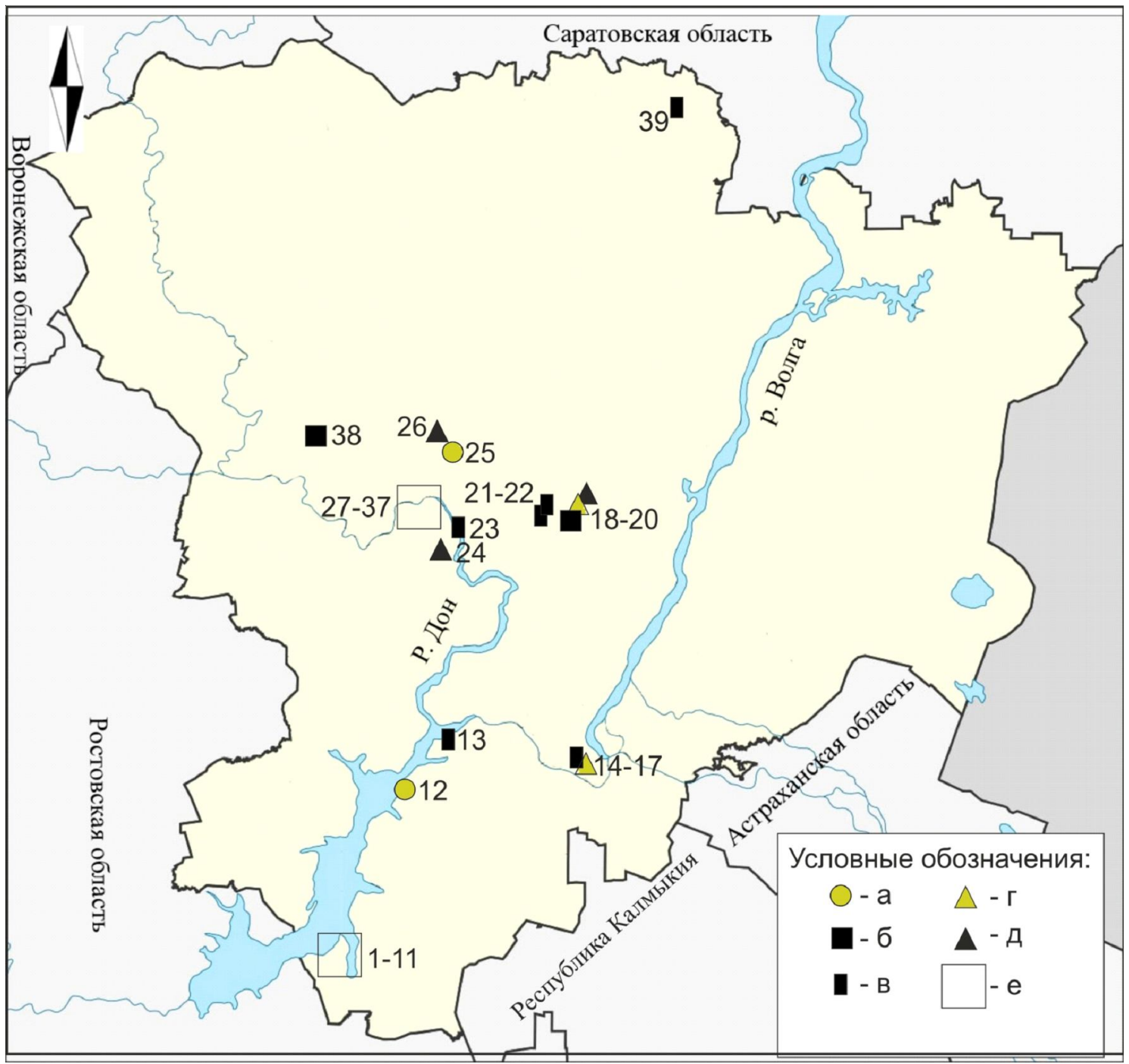

Рис. 1. Палеолитические и мезолитические памятники Волгоградской области (бассейн р. Дон):

( $a$ - памятники эпохи палеолита; $\sigma$ - памятники среднего палеолита;

в - памятники верхнего палеолита; г - памятники верхнего палеолита / мезолита; д - памятники мезолита;

$$
e \text { - локальное скопление памятников). }
$$

1-11 - район устья р. Курмоярский Аксай и прилегающий к нему участок побережья Цимлянского водохранилища;

12 - Логовское; 13 - Колпачки; 14-17 - Ивановка I-IV; 18-20 - Ютаевка I-III; 21-22 - Тары I-II;

23 - Новогригорьевская; 24 - Яровское; 25 - Шлях; 26 - Фроловская; 27-37 - район станицы Кременской; 38 - Шашкин; 39 - Александровка

Fig. 1. Paleolithic and Mesolithic sites of the Volgograd oblast (the Volga basin):

( $a$ - Paleolithic sites; $\sigma$ - Middle Paleolithic sites;

в - Upper Paleolithic sites; 2 - Upper Paleolithic - Mesolithic sites; $\partial$ - Mesolithic sites;

$e-$ local accumulations of sites).

1-11 - The area of the Kurmoyarsky Aksai River mouth and the adjacent section of the Tsimlyansk Reservoir ashore; 12 - Logovskoe; 13 - Kolpachki; 14-17 - Ivanovka I-IV; 18-20 - Yutaevka I-III; 21-22 - Tary I-II;

23 - Novogrigor'evskaya; 24 - Yarovskoe; 25 - Shlyah, 26 - Frolovskaya; 27-37 - rayon stanicy Kremenskoy; 38 - Shashkin; 39 - Aleksandrovka 


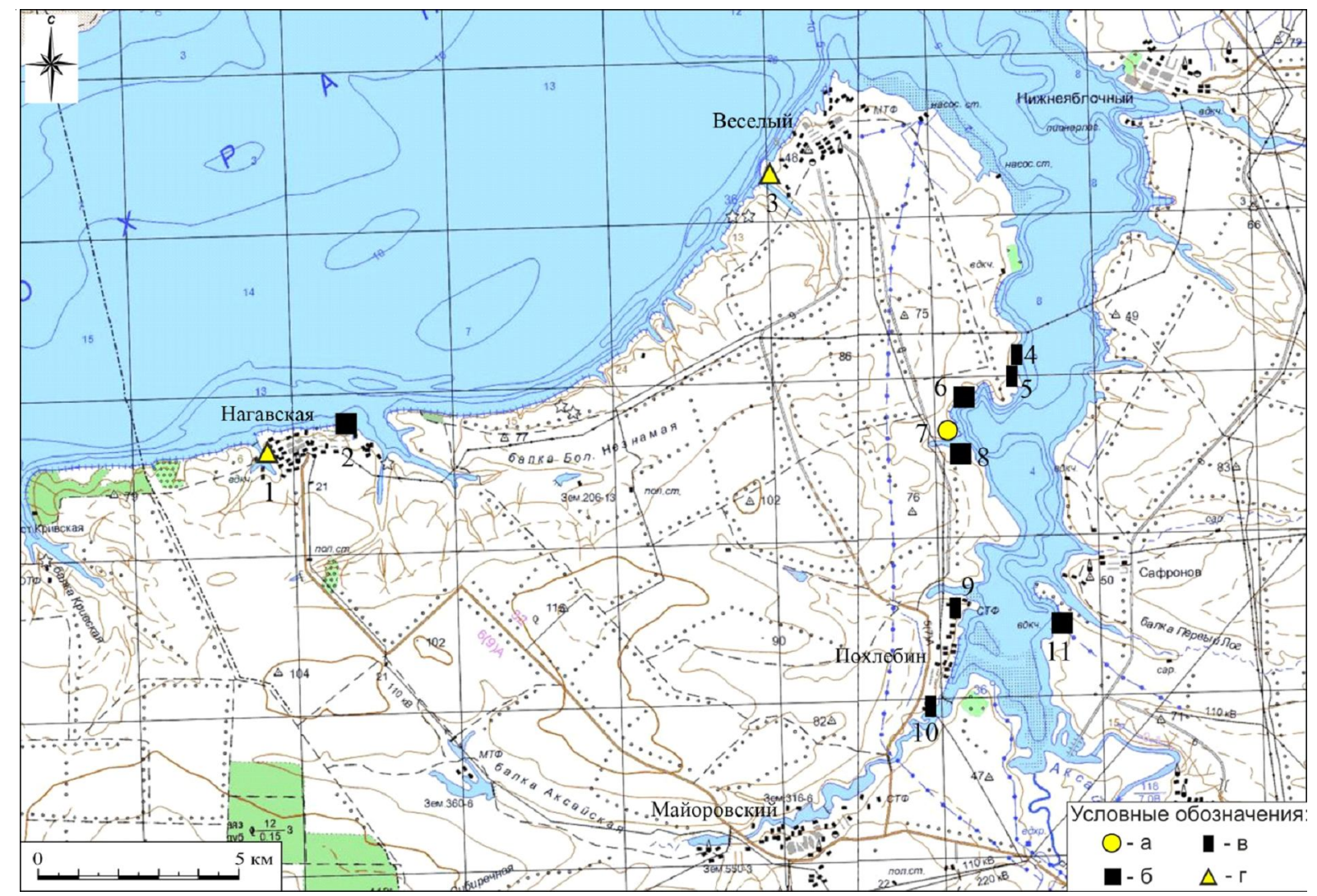

Рис. 2. Палеолитические и мезолитические памятники в районе устья р. Курмоярский Аксай и прилегающего к нему участка побережья Цимлянского водохранилища:

( $a$ - памятники эпохи палеолита; $\sigma$ - памятники среднего палеолита;

8 - памятники верхнего палеолита; 2 - памятники верхнего палеолита / мезолита).

1-2 - Нагавская I-II; 3 - Веселый; 4-5 - Подгородниченково I-II; 6-8 - Козловая балка; 9-10 - Похлебино I-II; 11 - Цыганский хутор

Fig. 2. Paleolithic and Mesolithic sites in the area of the Kurmoyarsky Aksai River mouth and the adjacent section of the Tsimlyansk Reservoir ashore:

( $a$ - Paleolithic sites; $\sigma$ - Middle Paleolithic sites;

в - Upper Paleolithic sites; 2 - Upper Paleolithic - Mesolithic sites).

1-2 - Nagavskaya I-II; 3 - Veselyy; 4-5 - Podgorodnichenkovo I-II; 6-8 - Kozlovaya balka;

9-10 - Pohlebino I-II; 11 - Cyganskiy hutor 
S.O. Remizov. Investigation of the Palaeolithic and Mesolithic Sites

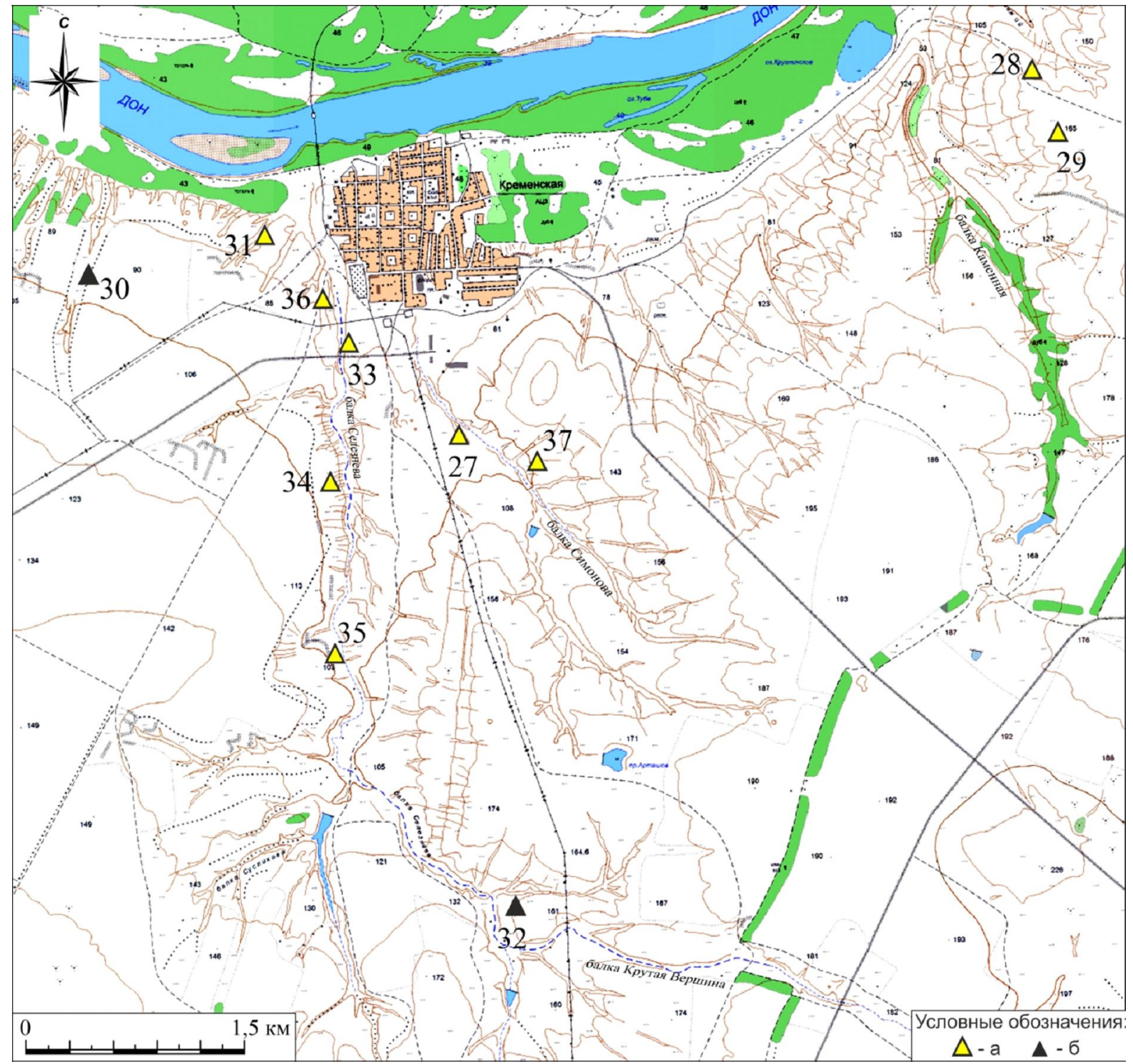

Рис. 3. Палеолитические и мезолитические памятники в районе станицы Кременской:

( $a$ - памятники верхнего палеолита / мезолита; $\sigma$ - памятники мезолита).

27-30 - Кременская I-IV; 31 - Доломановская балка; 32-36 - Селезневское I-V; 37 - Симоновское

Fig. 3. Paleolithic and Mesolithic sites in the area of Kremenskaya village:

( $a$ - Upper Paleolithic - Mesolithic sites; $\sigma$ - Mesolithic sites).

27-30 - Kremenskaya I-IV; 31 - Dolomanovskaya balka; 32-36 - Seleznevskoe I-V; 37 - Simonovskoe 


\section{СПИСОК ЛИТЕРАТУРЫ}

Баллод Ф. В., 1923. Приволжские Помпеи (Опыт художественно-археологического обследования части правобережной Саратовско-Царицынской приволжской полосы). М. : Госиздат. 132 с.

Береговая Н. А., 1984. Палеолитические местонахождения СССР (1958-1970). Л. : Наука. 172 с.

Вишняцкий Л. Б., 1999. Отчет о полевых исследованиях разведочного отряда Среднедонской экспедиции в 1999 году // Архив ИИМК РАН. РО. Ф. 35. Д. 22. 7 с.

Вишняцкий Л. Б., 2000. Отчет о полевых исследованиях разведочного отряда Среднедонской экспедиции в 2000 году // Архив ИИМК РАН. РО. Ф. 35. КП 5301. 24 с.

Горецкий Г. И., 1952. Следы палеолита и мезолита в Нижнем Подонье // Советская археология. Т. XVI. С. $302-319$.

Ильина А. И., Шишкин П. Н., 1929. Материалы к археологической карте Сталинградского, Хопёрского и некоторой части Астраханского и Камышынского округов Нижне-Волжского края. Сталинград : Нижне-Волжское издательство. 50 с.

Куфенко В. И., 1990. Александровка I - памятник эпохи верхнего палеолита на р. Медведице // Древности Волго-Донских степей. Вып. 1. Волгоград : Изд-во Волгоградского Госпединституга. С. 64-71.

Малов Н. М., 2012. Археология Поволжья : учеб. пособие для студентов Института истории и международных отношений Саратовского ГУ. Саратов : Изд-во СГУ. 122 с.

Минаева Т. М., 1929. Кремневая индустрия Нижнего Поволжья // Труды Нижне-Волжского областного научного общества краеведения. Вып. 36, ч. 1. Саратов : Изд-во Нижне-Волжского общества краеведения. C. 3-27.

Минх А. Н., 1898. Историко-географический словарь Саратовской губернии. Т. 1. Южные уезды: Камышинский и Царицынский. Вып. 1. Лит. А-Г. Саратов. 1409 с.

Нехорошев П. Е., 1990. Отчет о полевых исследованиях Среднедонской палеолитической экспедиции в 1990 году // Архив ИИМК РАН. РО. Ф. 35. Д. 77.40 с.

Нехорошев П. Е., 1991. Отчет о полевых исследованиях Среднедонской палеолитической экспедиции в 1991 году // Архив ИИМК РАН. РО. Ф. 35. Д. 186.40 с.

Нехорошев П. Е., 1992а. Исследования Среднедонской палеолитической экспедиции // Древности ВолгоДонских степей. Вып. 2. Волгоград : Перемена. С. 14-16.

Нехорошев П. Е., 1992б. Технология расщепления камня мустьерской стоянки Шлях (предварительные данные) // Проблемы палеолита и мезолита Волго-Уралья : тезисы регионального совещания. Саратов : Изд-во Саратовского университета. С. 28-30.

Нехорошев П. Е., 1994. Новая верхнепалеолитическая стоянка на Среднем Дону // Древности Волго-Донских степей. Вып. 4. Волгоград : Перемена. С. 81-88.

Нехорошев П. Е., 1995. Местонахождение каменного века у станицы Кременской // Древности Волго-Донских степей. Вып. 5. Волгоград : Перемена. С. 53-57.

Нехорошев П. Е., 1999. Отчет о полевых исследованиях Среднедонской палеолитической экспедиции // Архив ИИМК РАН. РО. Ф. 35. ОП. 1. Д. 19-20. 20 с.

Нехорошев П. Е., 2000. Отчет об исследовании палеолитической стоянки Шлях Фроловского р-на Волгоградской обл. в 2000 году // Архив ИИМК РАН. РО. Ф. 35. Оп. 1. Д. 20-21. 39 с.

Нехорошев П. Е., 2001. Отчет об исследовании палеолитической стоянки Шлях Фроловского р-на Волгоградской обл. в 2001 году // Архив ИИМК РАН. РО. Ф. 35. Оп. 1. Д. 28-29. 76 с.

Нехорошев П. Е., 2006а. Новогригорьевская стоянка // Археология Нижнего Поволжья. Т. 1. Каменный век. Волгоград : Волгоградское научное издательство. С. 75-79.

Нехорошев П. Е., 2006б. Стоянка Шлях // Археология Нижнего Поволжья. Т. 1. Каменный век. Волгоград : Волгоградское научное издательство. С. 27-61.

Нехорошев П. Е., Вишняцкий Л. Б., Очередной А. А., 2015. Исследования палеолитической стоянки Шлях // Археологические открытия 2010-2013 годов. М. : Наука. С. 406.

Праслов Н. Д., 1965. Отчет о поисках палеолита в Волго-Донском междуречье в 1965 году // Архив ИИМК РАН. РО. Ф. 35. ОП. 1. Д. 186. 25 с.

Праслов Н. Д., 1966. Отчет о разведывательных работах по каменному веку на Нижнем Дону и в Калмыкии // Архив ИИМК РАН. РО. Ф. 35. ОП. 1.27 с. 
Праслов Н. Д., 1967. Поиски палеолита в Волго-Донском междуречье // Бюллетень комиссии по изучению четвертичного периода Академии наук СССР. № 34. М. : Наука. С. 120-126.

Праслов Н. Д., 1968. Ранний палеолит Северо-Восточного Приазовья и Нижнего Дона. Материалы и исследования по археологии СССР. № 157. Л. : Наука. 156 p.

Праслов Н. Д., 1970. Археологические разведки на юго-востоке Приволжской возвышенности // Археологические открытия 1969 года. М. : Наука. С. 85-86.

Праслов Н. Д., 1971. Отчет о полевых работах палеолитического отряда Волго-Донской экспедиции в 1971 году // Архив ИИМК РАН. РО. Ф. 35. Оп. 1. Д. 70.25 с.

Праслов Н. Д., 1984. Ранний палеолит Русской равнины и Крыма // Археология СССР. Палеолит СССР. М. : Наука. С. 94-134.

Праслов Н. Д., 1996. Открытие А.А. Иессеном первой палеолитической стоянки на Донской равнине // Между Азией и Европой. Кавказ в IV-I тыс. до н. э. : материалы конф., посвящ. 100-летию А.А. Иессена. СПб. : Изд-во ГЭ. С. 31-34.

Праслов Н. Д., 2001. Палеолит бассейна Дона (проблемы стратиграфии, хронологии и развития культуры) : автореф. дис. ... д-ра ист. наук. СПб. 46 с.

Ремизов С. О., 1992. Памятники палеолита Волгоградской области и перспектива их поиска // Проблемы палеолита и мезолита Волго-Уралья. Саратов : Изд-во СГУ. С. 35-37.

Ремизов С. О., 2000. Отчет о разведках во Фроловском и Клетском районах Волгоградской области в 1999 году. Волгоград// Архив ВОКМ. Ф. $159.8 \mathrm{c}$.

Ремизов С. О., 2001а. Отчет о разведках во Фроловском и Клетском районах Волгоградской области в 2000 году // Архив ВОКМ. Ф. 161.9 с.

Ремизов С. О., 2001б. Палеолит Волгоградской области: история исследования, условия залегания памятников и перспективы их поиска // Нижневолжский археологический вестник. Вып. 4. С. 240-243.

Ремизов С. О., 2002. Отчет об исследованиях во Фроловском и Иловлинском районах Волгоградской области в 2001 году // Архив МКУК «Фроловский городской краеведческий музей». РА. 10 с.

Ремизов С. О., 2003. Отчет об исследованиях в Иловлинском районе Волгоградской области в 2002 году // Архив ВОКМ. Ф. 179, 179а. 16 с.

Ремизов С. О., 2003-2004. Новая стоянка каменного века на территории Волгоградской области // Stratum plus. № 1. Кишинев : Изд-во ун-та «Высшая антропологическая школа». С. 267-270.

Ремизов С. О., 2005. Отчет об археологических исследованиях на Яровском местонахождении в Иловлинском районе Волгоградской области в 2004 году // Архив музея-заповедника «Старая Сарепта». НВФ. № 3063.18 с.

Ремизов С. О., 2019. Исследования памятников палеолита и мезолита в бассейне Волги на территории Волгоградской области // Записки Института истории материальной культуры РАН. № 20. СПб. : Нев. Книж. Тип. С. 174-191. DOI: https://doi.org/10.31600/2310-6557-2019-20-174-191.

Ярков А. А., 2005. Ожившие драконы. Волгоград : Волгоградское научное издательство. 363 с.

\section{REFERENCES}

Ballod F.V., 1923. Privolzhskie Pompei (Opyt hudozhestvenno-arheologicheskogo obsledovaniya chasti pravoberezhnoy Saratovsko-Caricynskoy privolzhskoy polosy) [Volga Pompeii (Experience of Artistic and Archaeological Survey at the Right-Bank Part of the Saratov-Tsaritsyn Belt of the Volga)]. Moscow, Gosudarstvennoe izdatel'stvo Publ. 132 p.

Beregovaya N.A., 1984. Paleoliticheskie mestonahozhdeniya SSSR (1958-1970) [Paleolithic Sites of the USSR (1958-1970)]. Leningrad, Nauka Publ. 172 p.

Vishniatsky L.B., 1999. Otchet o polevyh issledovaniyah razvedochnogo otryada Srednedonskoy ekspedicii v 1999 godu [Report on the Field Works of the Middle Don Expedition in 1999]. Arkhiv IIMK RAN. RO. F. 35. D. $22.7 \mathrm{p}$.

Vishniatsky L.B., 2000. Otchet o polevyh issledovaniyah razvedochnogo otryada Srednedonskoy ekspedicii v 2000 godu [Report on the Field Works of the Middle Don Expedition in 1999]. Arkhiv IIMK RAN. RO. F. 35. KP 5301.24 p. 
Goretsky G.I. 1952. Sledy paleolita i mezolita v Nizhnem Podon'e [Traces of the Palaeolithic and Mesolithic in the Lower Don Area]. Sovetskaya arheologiya [Soviet Archaeology], vol. XVI, pp. 302-319.

Ilyina A.I., Shishkin P.N., 1929. Materialy k arheologicheskoy karte Stalingradskogo, Hopyorskogo i nekotoroyy chasti Astrahanskogo i Kamyshynskogo okrugov Nizhne-Volzhskogo kraya [Materials for the Archaeological Map of the Stalingrad', Khopersky' and Some Parts of the Astrakhan' and Kamyshyn' Districts of the Lower Volga Region]. Stalingrad, Nizhne-Volzhskoe izdatel'stvo Publ. 50 p.

Kufenko V.I., 1990. Aleksandrovka I- pamyatnik epohi verhnego paleolita na r. Medvedice [Aleksandrovka I as the Upper Palaeolithic Site on the Medveditsa River]. Drevnosti Volgo-Donskih stepey [Antiquities of the VolgaDon steppes], iss. 2. Volgograd, VSPI, pp. 64-71.

Malov N.M., 2012. Arheologiya Povolzh'ya: uchebnoye posobie dlya studentov Instituta istorii i mezhdunarodnyh otnosheniy Saratovskogo Gosudarstvennogo universiteta [Volga Archeology: a Manual for Students of the Institute of History and International Relations of the Saratov State University]. Saratov, SSU, 122 p.

Minaeva T.M., 1929. Kremnevaya industriya Nizhnego Povolzh'ya [Lithic Assemblage of the Lower Volga Region]. Trudy Nizhne-Volzhskogo oblastnogo nauchnogo obshchestva kraevedeniya [Proceedings of the Lower Volga Regional Scientific Society for the Study of Local History], vol. 36, part 1. Saratov, Nizhne-Volzhskoe obshchestvo kraevedeniya Publ., pp. 3-27.

Minh A.N., 1898. Istoriko-geograficheskiy slovar' Saratovskoy gubernii. Yuzhnye uezdy: Kamyshinskiy i Tsaritsynskiy [Historical-Geographical Dictionary of the Saratov Province. Southern districts: Kamyshinsky and Tsaritsinsky], vol. 1, iss. 1, lit. A-G. Saratov. 1409 p.

Nekhoroshev P.E. 1990. Otchyot o polevyh issledovaniyah Srednedonskoy paleoliticheskoy ekspeditsii v 1990 godu [Report on the Field Works of the Middle Don Paleolithic Expedition in 1990]. Arkhiv IIMK RAN. RO. F. 35. D. $77.40 \mathrm{p}$.

Nekhoroshev P.E., 1991. Otchyot o polevyh issledovaniyah Srednedonskoy paleoliticheskoy ekspeditsii v 1991 godu [Report on the Field Works of the Middle Don Paleolithic Expedition in 1991]. Arkhiv IIMK RAN. RO. F. 35. D. $186.40 \mathrm{p}$.

Nekhoroshev P.E., 1992a. Issledovaniya Srednedonskoy paleoliticheskoy ekspeditsii [Investigations of the Middle Don Paleolithic Expedition]. Drevnosti Volgo-Donskih stepey [Antiquities of the Volga-Don Steppes], iss. 2. Volgograd, Peremena Publ, pp. 14-16.

Nekhoroshev P.E., 19926. Tekhnologiya rasshchepleniya kamnya must'erskoy stoyanki Shlyah (predvaritel'nye dannye) [The Technology of Stone Knapping at the Mousterian Site Shl'ah (preliminary data)]. Problemy paleolita i mezolita Volgo-Ural'ya: tezisy regional'nogo soveshchaniya [Problems of the Paleolithic and Mesolithic of the Volga-Ural. Abstracts of the Regional Meeting]. Saratov, SSU, pp. 28-30.

Nekhoroshev P.E., 1994. Novaya verhnepaleoliticheskaya stoyanka na Srednem Donu [New Upper Palaeolithic Site on the Middle Don]. Drevnosti Volgo-Donskih stepey [Antiquities of the Volga-Don Steppes], iss. 4. Volgograd, Peremena Publ., pp. 81-88.

Nekhoroshev P.E., 1995. Mestonahozhdenie kamennogo veka u stanitsy Kremenskoy [Surface Location of the Stone Age Materials at the Kremenskaya Village]. Drevnosti Volgo-Donskih stepey [Antiquities of the VolgaDon steppes], iss. 5. Volgograd, Peremena Publ., pp. 53-57.

Nekhoroshev P.E., 1999. Otchyot o polevyh issledovaniyah Srednedonskoy paleoliticheskoy ekspeditsii v 1999 godu [Report on the Field Works of the Middle Don Paleolithic Expedition in 1990]. Arkhiv IIMK RAN. RO. F. 35. Op. 1. D. 19-20.20 p.

Nekhoroshev P.E., 2000. Otchyot o polevyh issledovaniyah Srednedonskoy paleoliticheskoy ekspeditsii v 2000 godu [Report on the Field Works of the Middle Don Paleolithic Expedition in 1990]. Arkhiv IIMK RAN. RO. F. 35. Op. 1. D. 20-21.39p.

Nekhoroshev P.E., 2001. Otchyot o polevyh issledovaniyah Srednedonskoy paleoliticheskoy ekspeditsii v 2001 godu [Report on the Field Works of the Middle Don Paleolithic Expedition in 1990]. Arkhiv IIMK RAN. RO. F. 35. Op. 1. D. 28-29.76 p.

Nekhoroshev P.E., 2006a. Novogrigor'evskaya stoyanka [Novogrigoryevskaya Site]. Arheologiya Nizhnego Povolzh'ya. Kamennyy vek [Archeology of the Lower Volga. Stone Age], vol. 1. Volgogral, Volgogradskoe nauchnoe izd-vo Publ., pp. 75-79.

Nekhoroshev P.E. 2006б. Stoyanka Shlyah [The Site of Shl'ah]. Arheologiya Nizhnego Povolzh'ya. Kamennyy vek [Archeology of the Lower Volga. Stone Age], vol. 1. Volgograd, Volgogradskoe nauchnoe izd-vo Publ., pp. 27-61. 
Nekhoroshev P.E., Vishniatsky L.B., Otcherednoy A.A., 2015. Investigations of the Palaeolithic site Shlyah. Arheologicheskie otkrytiya 2010-2013 godov [Archaeological Discoveries 2010-2013]. Moscow, Nauka Publ, pp. 406.

Praslov N.D., 1965. Otchet o poiskah paleolita v Volgo-Donskom mezhdurech'e v 1965 godu [Report on the Search of the Paleolithic in the Volga-Don Interfluve in 1965]. Arkhiv IIMK RAN. RO. F. 35. Op. 1. D. 186. 25 p.

Praslov N.D., 1966. Otchet o poiskakh paleolita v Volgo-Donskom mezhdurech'e v 1965 godu [Report on Investigation Works on the Stone Age on the Lower Don and in Kalmykia]. Arkhiv IIMK RAN. RO. F. 35. Op. 1. D. 28-29. 27 p.

Praslov N.D., 1967. Poiski paleolita v Volgo-Donskom mezhdurech'e [Searches for the Paleolithic at the Volga-Don Interfluve]. Bulleten' komissii po izucheniyu chetvertichnogo perioda Akademii nauk SSSR [Bulletin of the Commission for the Study of the Quaternary Period Of the Academy of Sciences of the USSR], no. 34, pp. 120-126.

Praslov N.D., 1968. Ranniy paleolit Severo-Vostochnogo Priazov'ya i Nizhnego Dona [Early Paleolithic of the North-East Azov and Lower Don]. Materialy i issledovaniya po arkheologii SSSR, no. 157. Leningrad, Nauka Publ., Leningradskoe otdelenie. $156 \mathrm{p}$.

Praslov N.D., 1970. Arheologicheskie razvedki na yugo-vostoke Privolzhskoy vozvyshennosti [Archaeological Field Works at the Volga Upland's Southeast]. Arheologicheskie otkrytiya 1969 goda [Archaeological Discoveries 1969]. Moscow, Nauka Publ., pp. 85-86.

Praslov N.D., 1971. Otchet o polevyh rabotah paleoliticheskogo otryada Volgo-Donskoy ekspeditsii v 1971 godu [Report on the Field Work of the Paleolithic Part of the Volga-Don Expedition in 1971]. Arkhiv IIMK RAN. RO. F. 35. Op. 1, D. 70.25 p.

Praslov N.D., 1984. Ranniy paleolit Russkoy ravniny i Kryma [Early Paleolithic of the Russian plain and Crimea]. Arheologiya SSSR. Paleolit SSSR [Archaeology of USSR. Paleolithic of USSR]. Moscow, Nauka Publ., pp. 94-134.

Praslov N.D., 1996. Otkrytie A.A. Iessenom pervoy paleoliticheskoy stoyanki na Donskoy ravnine [Discovery by A.A. Iessen of the First Palaeolithic Site on the Don Plain]. Mezhdu Aziey i Evropoy. Kavkaz v IV-I tys. do n.e.: materialy konf., posvyashch. 100-letiyu A.A. Iessena [Between Asia and Europe. Caucasus in IVI millennium BC. Materials of the Conference Dedicated to the $100^{\text {th }}$ Anniversary of A.A. Iessen]. Saint Petersburg, The State Hermitage Museum, pp. 31-34.

Praslov N.D., 2001. Paleolit basseyna Dona (problemy stratigrafii, hronologii i razvitiya kul tury): avtoref. dis. ... d-ra ist. nauk [The Palaeolithic in the Don Bassin (Issues of Stratigraphy, Chronology and the Development of Culture). Drt. hist. sci. abs. diss.]. Saint Petersburg. 46 p.

Remizov S.O., 1992. Pamyatniki paleolita Volgogradskoy oblasti i perspektiva ih poiska [Paleolithic Sites of the Volgograd Region and the Prospect of theirs Search]. Problemy paleolita i mezolita Volgo-Ural'ya [Problems of the Paleolithic and Mesolithic of the Volga-Urals]. Saratov, SSU, pp. 35-37.

Remizov S.O., 2000. Otchet o razvedkah vo Frolovskom i Kletskom rayonah Volgogradskoy oblasti v 1999 godu [Report on the Field Works at the Frolovsky and Kletsky Districts of the Volgograd Region in 1999].Volgograd. Arkhiv VOKM. F. 159.8 p.

Remizov S.O., 2001a. Otchet o razvedkah vo Frolovskom i Kletskom rayonah Volgogradskoy oblasti v 2000 godu [Report on the Field Works in the Frolovsky and Kletsky Districts of the Volgograd Region in 2000]. Arkhiv VOKM, F. 161.9 p.

Remizov S.O., 20016. Paleolit Volgogradskoy oblasti: istoriya issledovaniya, usloviya zaleganiya pamyatnikov i perspektivy ih poiska [Paleolithic of the Volgograd region: History of Study, Conditions of the Sites Positions and Prospects for Their Search]. Nizhnevolzhskiy arheologicheskiy vestnik [The Lower Volga Archaeological Bulletin], iss. 4, pp. 240-243.

Remizov S.O., 2002. Otchet ob issledovaniyah vo Frolovskom i Ilovlinskom rayonah Vol-gogradskoy oblasti v 2001 godu [Report on the Field Works at the Frolovsk and Ilovlinsky Districts of the Volgograd Region in 2001]. Arkhiv VOKM. 10 p.

Remizov S.O., 2003. Otchet ob issledovaniyah v Ilovlinskom rayonah Volgogradskoy oblasti v 2002 godu [Report on the field works at the Frolovsk and Ilovlinsky districts of the Volgograd region in 2001]. Arkhiv VOKM, F. 179, 179a. 16p.

Remizov S.O., 2003-2004. Novaya stoyanka kamennogo veka na territorii Volgogradskoy oblasti [New Stone Age Site at the Volgograd Region]. Stratum plus, no. 1. Kishinev, Publ. of University "High anthropological School”. p. 267-270. 
Remizov S.O., 2005. Otchet ob arheologicheskih issledovaniyah na Yarovskom mestonahozhdenii v Ilovlinskom rayone Volgogradskoy oblasti v 2004 godu [Report on Archaeological Field Works at the Yarovsky Surface Locality in the Ilovlinsky District of the Volgograd Region in 2004]. Arkhiv muzeya-zapovednika «Staraya Sarepta». NVF, no. 3063. 18 p.

Remizov S.O., 2019. Issledovaniya pamyatnikov paleolita i mezolita v basseyne Volgi na territorii Volgogradskoy oblasti [Paleolithic and Mesolithic Sites in the Volga Basin on the Territory of Volgograd Oblast]. Zapiski Instituta Istorii Material'noy Kul 'tury RAN [Transactions of the Institute for the History of Material Culture], no. 20, pp. 174-191. DOI: https://doi.org/10.31600/2310-6557-2019-20-174-191.

Yarkov A. A., 2005. Ozhivshie drakony [The Revived Dragons]. Volgograd, Volgogradskoe nauchnoe izdatelstvo Publ. 363 p.

\section{Information About the Author}

Stanislav O. Remizov, Head of the Sector of Archeology, Historical, Ethnographic and Architectural Museum-Preserve "Old Sarepta”, Izobilnaya St., 10, 400026 Volgograd, Russian Federation, paleostas@yandex.ru, https://orcid.org/0000-0001-9892-8058

\section{Информация об авторе}

Станислав Олегович Ремизов, заведующий сектором археологии, Историко-этнографический и архитектурный музей-заповедник «Старая Сарепта», ул. Изобильная, 10, 400026 г. Волгоград, Российская Федерация, paleostas@yandex.ru, https://orcid.org/0000-0001-9892-8058 